\title{
Tissue distribution and excretion of the five components of Portulaca oleracea L. extract in rat assessed by UHPLC
}

\author{
Wenjie Zhang',**, Di Li ${ }^{1}$, Aijing Leng ${ }^{2}$, Junjun $\mathrm{Ai}^{1}$, Yang Du ${ }^{2}$, Yihan Meng ${ }^{1}$, Yucong Gao ${ }^{1}$, \\ Xixiang Ying ${ }^{1}$
}

\author{
${ }^{1}$ School of Pharmacy, Liaoning University of Traditional Chinese Medicine, Dalian, China, ${ }^{2}$ First Affiliated Hospital of Dalian \\ Medical University, Dalian, China
}

\begin{abstract}
The aim of the present study was to investigate the tissue distribution and excretion of five components of Portulaca oleracea L. extract (POE) in rat following oral administration. A rapid, sensitive and specific ultra-high performance liquid chromatography (UHPLC) method with puerarin as the internal standard was used for the quantitative analysis of five components of POE, including caffeic acid (CA), $p$-coumaric acid ( $p$-CA), ferulic acid (FA), quercitrin (QUER) and hesperidin (HP) in rat tissues including the liver, intestine, stomach, muscle, heart, lung, brain, kidney and spleen, urine and feces. The results show that only $p$-CA and FA were found in nearly all tissues with low cumulative ratios, and CA was higher in the intestine and stomach with a slightly higher cumulative ratio in the urine and feces after $24 \mathrm{~h}$. HP and QUER were found at low levels in the tissues with low cumulative ratios.
\end{abstract}

Uniterms: Portulaca oleracea L./pharmacokinetics. Portulaca oleracea L./extract/experimental study. Portulaca oleracea L./extract/ tissue distribution. Portulaca oleracea L./extrato/excretion. Compostos fenólicos. Ultra performance liquid chromatography/quantitative analysis.

O objetivo do presente estudo foi investigar a distribuição tecidual e excreção de cinco componentes de extrato Portulaca oleracea L. (POE) em ratos após administração oral. Um método analítico rápido, sensível e específico para quantificação de cinco componentes de POE (ácido cafeico (CA), ácido p-cumárico ( $p$-CA), ácido ferúlico (FA), quercitrina (QUER) e hesperidina (HP)) por cromatografia líquida de ultra eficiência (UHPLC), empregando puerarina como padrão interno de referência. Os compostos foram quantificados em diferentes tecidos dos animais, sendo eles fígado, intestino, estômago, músculo, coração, pulmão, cérebro, rim e baço, urina e fezes. Os resultados mostraram que apenas $p$-CA e FA foram encontradas em todos os tecidos com baixas taxas cumulativas e CA apresentou níveis mais altos no intestino e estômago com a taxa cumulativa um pouco mais elevada na urina e nas fezes após $24 \mathrm{~h}$. HP e QUER apresentaram baixas concentrações nos tecidos com baixas taxas cumulativas.

Uniterms: Portulaca oleracea L./farmacocinética. Portulaca oleracea L./extrato/estudo experimental. Portulaca oleracea L./extrato/distribuição tecidual. Portulaca oleracea L./extrato/excreção. Compostos fenólicos. Cromatografia líquida de ultra eficiência/análise quantitativa.

\section{INTRODUCTION}

Portulaca oleracea L. is a well-known traditional Chinese medicine and is recorded in the Chinese pharmacopoeia (PRC, 2010). It has historically been used for removing heat, counteracting toxicity, cooling the blood, hemostasis and treating dysentery. As P. oleracea L. is also a widespread and abundant plant in the world,

\footnotetext{
*Correspondence: Wenjie Zhang. School of Pharmacy. Liaoning University of Traditional Chinese Medicine. 77 Shengming 1 Road, DD Port - 116600 Dalian, China. E-mail: wenjiezhang509@hotmail.com
}

much attention has been paid to its pharmacological study, such as its anti-inflammatory and anti-pruritic (Lim et al., 2011), hypocholesterolemic (Movahedian, Ghannadi, Vashimia, 2007) and hypoglycemic (Gong et al., 2009) effects. Some reports have focused on in vitro and in vivo analyses of the components in P. oleracea L. extract (POE) i.e., flavonoids, by capillary electrophoresis with electrochemical detection (Xu, Yu, Chen, 2006), and four compounds of POE have been detected in rat plasma by HPLC after intravenous administration of $P$. oleracea L. (Cheng et al., 2012). However, there is little known regarding the tissue distribution and excretion of $\mathrm{POE}$. 
Therefore, a rapid, sensitive and specific UHPLC method with an internal standard was established to evaluate the tissue distribution and excretion of five components of Portulaca oleracea L. extract (POE), including caffeic acid (CA), $p$-coumaric acid ( $p$-CA), ferulic acid (FA), quercitrin (QUER) and hesperidin (HP), after oral administration in rats, which will fill in some of the gaps in our overall knowledge of POE.

\section{MATERIAL AND METHODS}

\section{Plant material}

Portulaca oleracea L. was collected from the collection site with the geographical coordinates $37^{\circ} 27^{\prime}$ $38^{\circ} 47^{\prime} \mathrm{N}, 113^{\circ} 30^{\prime}-115^{\circ} 20^{\prime} \mathrm{E}$ (Anguo, Hebei, China) in September 2013, and identified by Prof. Yanjun Zhai. A voucher specimen (No. 20130925) was deposited at the School of Pharmacy, Liaoning University of Traditional Chinese Medicine.

\section{Reagents and chemicals}

Puerarin as the internal standard (IS) and QUER were purchased from the National Institute for the Control of Pharmaceutical and Biological Products (Beijing, China), and CA, $p$-CA, FA and HP were obtained from Sichuan Weikeqi Biological Technology Co., Ltd (Chengdu, China). Figure 1 illustrates the chemical structures of the five investigated components and the IS. Methanol and acetonitrile were of HPLC grade provided by Damao Chemical Reagent Plant (Tianjin, China).
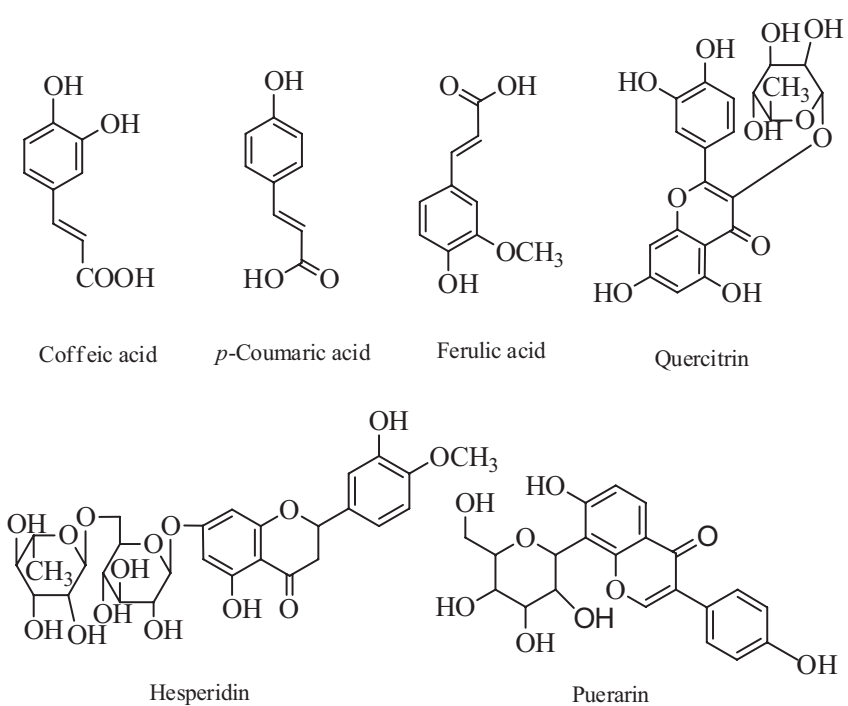

FIGURE 1 - Chemical structures of the five analytes and internal standard.
Purified water was obtained from Wahaha Group Ltd., Co. (Shenyang, China). All other reagents were of analytical grade purchased from Jinfeng Chemical Factory (Tianjin, China).

\section{Chromatographic system and conditions}

The analysis was performed on a NEXERA X2 UHPLC LC-30A system (Japan, Shimadzu) was equipped with a solvent delivery pump (LC-30AD), a vacuum degasser (DGU-20A), a Shimadzu UV-is spectrophotometric detector (SPD-20A) and LabStation software (Shimadzu). The analytes were determined on an analytical shim-pack ODS column $(75 \mathrm{~mm} \times 2 \mathrm{~mm}, 1.6 \mu \mathrm{m}$ particle size, Shimadzu, Japan) at a column temperature of $40^{\circ} \mathrm{C}$ incorporating a UV detector at a flow rate of 0.3 $\mathrm{mL} / \mathrm{min}$ with the detection wavelength set at $320 \mathrm{~nm}$. The mobile phase consisted of phase A (acetonitrile) and B ( $0.1 \%$ acetic acid aqueous) in a gradient elution: $8 \%$ A within $0-2 \mathrm{~min}, 16 \%$ A within $2-4 \mathrm{~min}, 17 \%$ A within 4-6 min, 25\% A within 6-7 min, 45\% A within 7-10 min and then returned to initial condition for a $10 \mathrm{~min}$ reequilibration, with a total run time of $20 \mathrm{~min}$. The mobile phase was passed under vacuum through a $0.22 \mu \mathrm{m}$ filter membrane and degassed by exposure to ultrasonic waves before use.

\section{Animals}

Male Wistar rats (body weight $300 \pm 20 \mathrm{~g}$ ) were provided by the Laboratory Animal Center of Dalian University (Dalian China). All rats were kept in a controlled environment for a week and had free access to standard laboratory food and water intake before the experiments. The rats were fasted overnight prior to the administration of POE. Animal experiments were carried out in accordance with the Guidelines for Animal Experimentation of Liaoning University of Traditional Chinese Medicine, and the procedure was approved by the Animal Ethics Committee of this institution (20140528).

\section{Preparation of the POE solution}

Whole dried P. oleracea L. (3 kg) was refluxed twice with water $(30 \mathrm{~L})$, each for $1 \mathrm{~h}$, then POE was obtained after the water was removed under reduced pressure. Then, the residue was passed through an AB- 8 macroporous resin column $(8 \times 100 \mathrm{~cm}$, Shanghai, China). To eliminate impurities, the column was eluted with $15 \mathrm{~L}$ of water and eluted with $30 \mathrm{~L}$ of $50 \%$ ethanol. After removing the ethanol of the $50 \%$ ethanol fraction in vacuo, the 
suspended solution of POE was obtained and stored at $4{ }^{\circ} \mathrm{C}$ prior to use. Using the external standard method for quantification, the contents of CA, $p$-CA, FA, QUER and $\mathrm{HP}$ in the suspended solution of extract were found to be $0.467,0.146,0.433,0.0738$ and $1.60 \mathrm{mg} / \mathrm{mL}$, respectively.

\section{Preparation of standards and quality control samples}

The stock solutions of the five standard compounds CA, $p$-CA, FA, QUER, HP and the IS were precisely weighed and dissolved using ultrasound in methanol, to yield concentrations of 235, 221, 327, 259, 242 and $212 \mathrm{ug} \cdot \mathrm{mL}^{-1}$, respectively.

For the tissue assay, five calibrators of CA ( 0.05 , $0.1,0.2,0.5,1.25$ and $\left.5.0 \mathrm{ug} \cdot \mathrm{mL}^{-1}\right), p$-CA $(0.05,0.1,0.2$, $0.5,1.25$ and $\left.5.0 \mathrm{ug} \cdot \mathrm{mL}^{-1}\right)$, FA $(0.1,0.2,0.4,1.0,2.5$ and $\left.10.0 \mathrm{ug} \cdot \mathrm{mL}^{-1}\right)$, QUER $(0.075,0.15,0.3,0.75,1.875$ and $\left.7.5 \mathrm{ug} \cdot \mathrm{mL}^{-1}\right)$ and $\mathrm{HP}\left(0.4,0.8,1.6,4,10\right.$ and $\left.40 \mathrm{ug} \cdot \mathrm{mL}^{-1}\right)$ were prepared by adding standard working solutions $(50 \mu \mathrm{L})$ and the IS $(10 \mu \mathrm{L})$ to drug-free rat tissues. All stock and working standard solutions were stored in brown bottles at $4^{\circ} \mathrm{C}$ until analysis. Quality control (QC) tissue samples were prepared at low, medium and high concentrations $\left(0.125,0.7\right.$ and $4 \mathrm{ug} \cdot \mathrm{mL}^{-1}$ for $\mathrm{CA}$ and $p$-CA; $0.25,1.4$ and $7.98 \mathrm{ug} \cdot \mathrm{mL}^{-1}$ for $\mathrm{FA} ; 0.1875,1.05$ and 5.985 $\mathrm{ug} \cdot \mathrm{mL}^{-1}$ for QUER; 1.0, 5.7 and $32 \mathrm{ug} \cdot \mathrm{mL}^{-1}$ for $\mathrm{HP}$ ) in bulk and aliquots were stored at $-20^{\circ} \mathrm{C}$ until analysis.

For the urine and feces assay, five calibrators of CA $\left(0.15,0.3,0.6,1.5,3.75\right.$ and $\left.15 \mathrm{ug} \cdot \mathrm{mL}^{-1}\right), p$-CA $(0.125$, $0.25,0.5,1,2.5$ and $\left.6.25 \mathrm{ug} \cdot \mathrm{mL}^{-1}\right)$, FA $(0.09,0.18,0.35$, $0.88,2.19$ and $\left.5.47 \mathrm{ug} \cdot \mathrm{mL}^{-1}\right)$, QUER $(0.19,0.38,0.75$, $1.88,4.69$ and $\left.18.75 \mathrm{ug} \cdot \mathrm{mL}^{-1}\right)$, and $\operatorname{HP}(1.25,2.5,5,10$, 25 and $\left.75 \mathrm{ug} \cdot \mathrm{mL}^{-1}\right)$ were prepared by adding standard working solutions $(50 \mu \mathrm{L})$ and IS $(50 \mu \mathrm{L})$ to drug-free rat urine/fecal samples. All stock and working standard solutions were stored in brown bottles at $4^{\circ} \mathrm{C}$ until analysis. The quality control (QC) samples of urine/feces were prepared at low, medium and high concentrations $\left(0.38,4.25\right.$ and $48.00 \mathrm{ug} \cdot \mathrm{mL}^{-1}$ for $\mathrm{CA} ; 0.63,7.07$ and $80.00 \mathrm{ug} \cdot \mathrm{mL}^{-1}$ for $p$-CA; $0.22,3.91$ and $70.00 \mathrm{ug} \cdot \mathrm{mL}^{-1}$ for FA; $0.1875,0.47,5.30$ and $60.00 \mathrm{ug} \cdot \mathrm{mL}^{-1}$ for QUER; 3.13, 13.69 and $60.00 \mathrm{ug} \cdot \mathrm{mL}^{-1}$ for $\mathrm{HP}$ ) in bulk and aliquots were stored at $-20{ }^{\circ} \mathrm{C}$ until analysis.

\section{Preparation of biosamples}

Twenty-five rats were divided into five groups $(n=5)$ at random. All rats were orally dosed with POE at a dose of $8.4 \mathrm{~mL} \cdot \mathrm{kg}^{-1}$, (approximately equivalent to $3.92 \mathrm{mg} \cdot \mathrm{kg}^{-1}$ of CA, $1.23 \mathrm{mg} \cdot \mathrm{kg}^{-1}$ of $p$-CA, $3.64 \mathrm{mg} \cdot \mathrm{kg}^{-1}$ of FA, $0.62 \mathrm{mg} \cdot \mathrm{kg}^{-1}$ of QUER and $13.47 \mathrm{mg} \cdot \mathrm{kg}^{-1}$ of HP). Also, tens rat were divided into two groups $(n=5)$ at random for the urine and feces assay.

For the tissue assay, the dosed rats were sacrificed and tissues removed at 10, 30, 60, 90 and $150 \mathrm{~min}$. Tissues were collected, including liver, intestine, stomach, muscle, heart, lung, brain, kidney and spleen. All tissues were rinsed with physiological saline, blotted on filter paper and weighed (the contents of stomach and intestine were removed before rinsing). Approximately $0.2 \mathrm{~g}$ of each tissue was weighed out and homogenized in $0.5 \mathrm{~mL}$ of saline solution, then centrifuged at $3000 \mathrm{rpm}$ for $15 \mathrm{~min}$. Tissue samples were stored at $-20{ }^{\circ} \mathrm{C}$ until analysis.

The homogenized tissue samples $(0.2 \mathrm{~mL})$ were supplemented with $10 \mu \mathrm{L}$ of the IS, $20 \mu \mathrm{L}$ of acetic acid and $1 \mathrm{~mL}$ of methanol, followed by vortex mixing for $1 \mathrm{~min}$, then centrifuged at $3000 \mathrm{rpm}$ for $15 \mathrm{~min}$. The supernatant was collected and evaporated to dryness at $50{ }^{\circ} \mathrm{C}$ under a gentle stream of nitrogen. Then, the dried residue was reconstituted in $100 \mu \mathrm{L}$ of the initial mobile phase and centrifuged at 10,000 rpm for $10 \mathrm{~min}$. A $1 \mu \mathrm{L}$ aliquot of the supernatant was injected into the UHPLC system for analysis.

For the urine and feces assay, all the rats were housed in stainless-steel metabolism cages to collect urine and feces at $0-2 \mathrm{~h}, 2-4 \mathrm{~h}, 4-8 \mathrm{~h}, 8-12 \mathrm{~h}$ and $12-24 \mathrm{~h}$ post-dosing. Water and standard laboratory food were offered during the whole experiment. The volume of the each collected urine sample and the weight of each collected feces sample were respectively recorded. All the samples were stored at $-20^{\circ} \mathrm{C}$ until analysis.

Urine samples $(200 \mu \mathrm{L})$ were supplemented with $50 \mu \mathrm{L}$ of the IS, $20 \mu \mathrm{L}$ of acetic acid and $1 \mathrm{~mL}$ of methanol and pipetted, followed by vortex mixing for $1 \mathrm{~min}$. After centrifugation at $3000 \mathrm{rpm}$ for $15 \mathrm{~min}$, the supernatant was separated and evaporated to dryness under a gentle stream of nitrogen at $40^{\circ} \mathrm{C}$. The residue was reconstituted in $200 \mu \mathrm{L}$ of the mobile phase and centrifuged at 10,000 rpm for $10 \mathrm{~min}$. Then, a $1 \mu \mathrm{L}$ aliquot of the clean supernatant was injected into the UHPLC system for analysis.

About $0.2 \mathrm{~g}$ of feces was homogenized in $0.5 \mathrm{~mL}$ of physiological saline solution (w/v, 2/5). The homogenate was then supplemented with $50 \mu \mathrm{L}$ of the IS, $20 \mu \mathrm{L}$ of acetic acid and $1 \mathrm{~mL}$ of methanol, then treated further in a similar manner as the urine samples.

\section{Method validation}

\section{Selectivity}

The selectivity was determined by comparing chromatograms of mixed blank tissues/urine/feces obtained 
from five drug-free rats with those of corresponding standard tissue/urine/feces samples spiked with the five standard solutions and IS, as well as the biosamples obtained after oral administration of POE.

\section{Linearity, LOD and LLOQ}

The calibration curves of tissues were performed over the linear range of $0.05-5 \mathrm{ug} \cdot \mathrm{mL}^{-1} \mathrm{CA}, 0.05-5 \mathrm{ug} \cdot \mathrm{mL}^{-1}$ $p$-CA, 0.1-10 ug $\cdot \mathrm{mL}^{-1} \mathrm{FA}, 0.075-7.5 \mathrm{ug} \cdot \mathrm{mL}^{-1}$ QUER, and $0.4-40 \mathrm{ug} \cdot \mathrm{mL}^{-1} \mathrm{HP}$. The calibration curves of urine/feces were performed over the linear range of $0.15-60 \mathrm{ug} \cdot \mathrm{mL}^{-1}$ $\mathrm{CA}, 0.125-100 \mathrm{ug} \cdot \mathrm{mL}^{-1} p-\mathrm{CA}, 0.0875-87.5 \mathrm{ug} \cdot \mathrm{mL}^{-1}$ FA, $0.1875-75 \mathrm{ug} \cdot \mathrm{mL}^{-1}$ QUER, and $1.25-75 \mathrm{ug} \cdot \mathrm{mL}^{-1}$ HP). The calibration curves for each analyte in different tissue/urine/fecal samples were generated by plotting the area ratio of five compounds to the IS separately $v s$. the nominal concentration in the standard tissue/urine/fecal samples. Moreover, the weighted $\left(1 / \mathrm{c}^{2}\right)$ least-square linear regression was applied to obtain the regression equation. The LOD (limit of detection) was determined by diluting the QC samples stepwise, given as the signal-to-noise ratio $(\mathrm{S} / \mathrm{N}=3)$. The lower limit of quantification (LLOQ), considered to be the lowest concentration point in the calibration curves, displayed an acceptable accuracy (RE) within $\pm 15 \%$ and a precision of less than $20 \%$.

\section{Precision and accuracy}

Five replicates of QC tissue/urine/fecal samples at three concentrations were assessed to calculate the intraday precision and accuracy on the same day. Inter-day precision was determined by analyzing the QC tissue/ urine/feces samples over three consecutive days. The intra-day and inter-day precision were defined as the relative standard deviation, and accuracy was determined by calculating the relative error (RE).

\section{Extraction recovery}

The extraction recoveries of five compounds were determined by comparing the peak area of each compound from QC samples at three concentrations with that of the unextracted standard solutions containing the equivalent amount of analytes regarded as $100 \%$ recovery.

\section{Stability}

The stability of QC samples was investigated at three concentrations, i.e. low, medium and high. The short-term stability experiment was conducted at ambient temperature $\left(25^{\circ} \mathrm{C}\right)$ for $24 \mathrm{~h}$, and long-term stability was assessed after storage at $-20{ }^{\circ} \mathrm{C}$ for 1 month. The freeze $\left(-20{ }^{\circ} \mathrm{C}\right)$-thaw (room temperature) stability was assessed after three freeze-thaw cycles.

\section{RESULTS AND DISCUSSION}

\section{Method development and optimization}

In order to obtain suitable retention times and good separation for the five components in the POE and IS, different combinations of several mobile phases were chosen, i.e. methanol-water and acetonitrile-water. Comparatively, there existed a serious baseline drift and interference of endogenous components in the tissues with analytes using the methanol-water system; besides, we could not obtain satisfactory separation among the compounds in POE. These problems were ultimately solved by using acetonitrile-water as the mobile phase in gradient elution, into which some acetic acid was added in order to obtain perfect peak shapes.

Three different wavelengths $(270,320$ and 360 $\mathrm{nm})$ were chosen to achieve high sensitivity for the five investigated components of POE. Finally, a detection wavelength of $320 \mathrm{~nm}$ was applied for the simultaneous analysis of the five compounds with no interference.

\section{Method validation}

\section{Selectivity}

To determine the selectivity of this method, blank tissues/urine/feces, tissues/urine/feces spiked with known amounts of the five reference substances, and tissue/urine/ feces removed from rats after oral dosing with POE were analyzed. The chromatograms of the stomach were chosen as an example (Figure 2) and show that there were no interfering peaks in the region of the peaks of the analytes. The retention times of CA, IS, $p$-CA, FA, QUER, and HP were approximately at $3.61,4.42,5.24,6.25,7.11$ and 8.21 min, respectively. The total run time was 10 min.

\section{Linearity, LOD and LLOQ}

The calibration curves, correlation coefficients and linear ranges of the five compounds in each tissue are given in Table I. The LODs of the five components, i.e. CA, $p$-CA, FA, QUER and HP were 0.015, 0.015, 0.03, 0.0225 and $0.12 \mathrm{ug} \cdot \mathrm{mL}^{-1}$, respectively. The LLOQ of the five components was defined as the lowest concentration on the calibration curve with precision/accuracy within $20 \%$, verified by repeated analysis. The calibration curves, correlation coefficients and linear ranges of the five compounds in urine/feces are given in Table II. The LODs of the five components, i.e. CA, $p$-CA, FA, QUER and HP were $0.045,0.0375,0.026,0.056$ and 0.375 $\mathrm{ug} \cdot \mathrm{mL}^{-1}$, respectively. The LLOQ of the five components was defined as the lowest concentration on the calibration 

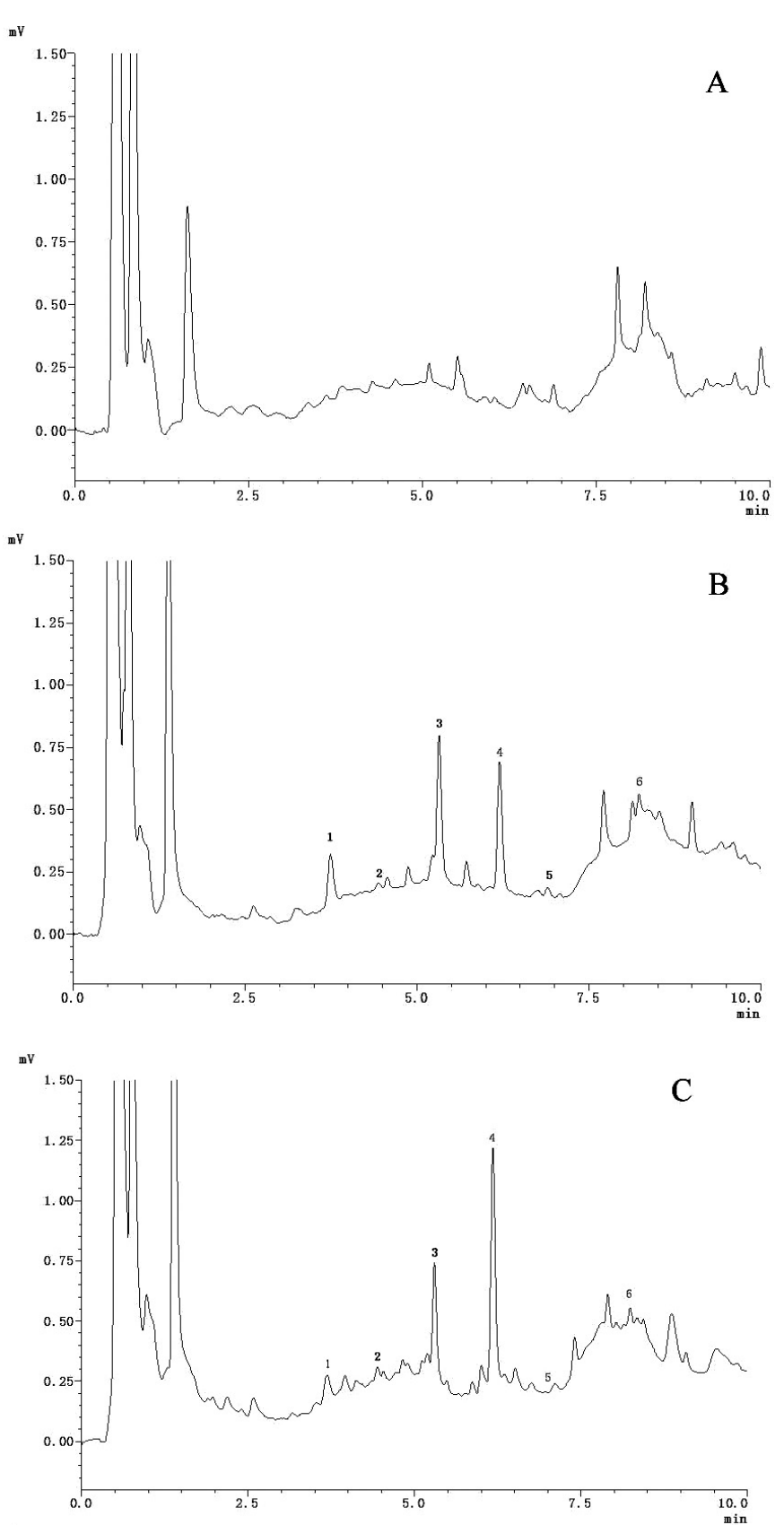

FIGURE 2 - Typical chromatograms A-C. Blank stomach sample A, blank stomach sample spiked with standard five compounds and IS B, and stomach sample after oral administration of POE at 90min C. (peak 1 CA; peak 2 IS.; peak 3 p-CA; peak 4 FA; peak 5 QUER; peak 6 HP).

curve with precision/accuracy within $20 \%$, verified by repeated analysis.

\section{Precision and accuracy}

The intra- and inter-day precision/accuracy of each analyte in the tissue QC samples at three concentrations are given in Table III. The intra- and inter-day precision/ accuracy of each analyte in the urine/feces QC samples at three concentrations are given in Tables IV/V. The RSDs of the five compounds were all $<20 \%$ for the intra-day and inter-day assays, which is in accordance with the guidance of the USFDA (FDA, 2001).

\section{Extraction recovery and stability}

Tables III-V show that the extraction recoveries of the five compounds in different tissues ranged from 82.14 $\pm 1.03 \%$ to $93.62 \pm 2.71 \%$, and that of the IS was $92.93 \pm$ $3.14 \%, 81.64 \pm 2.48 \%$ to $94.93 \pm 2.34 \%$ in the urine and $83.36 \pm 0.35 \%$ to $93.65 \pm 2.41 \%$ in the feces, demonstrating that there was negligible loss during extraction, which could be attributed to the high solubility of the analytes in methanol and the one-step protein precipitation used in the sample preparation. The results of the short-term stability, long-term stability and freeze-thaw stability also indicated that no remarkable degradation occurred during the chromatography, extraction and sample storage processes for excreta samples.

\section{Tissue distribution assay}

The concentrations of the five components in the nine tissues collected at 10,30, 60,90 and 150 min after oral administration of POE are shown in Table VI.

Although the chemical structures of CA, $p$-CA and FA were similar, their concentrations in the tissues were significantly different (Table VI). After oral administration of the POE in rats, only $p$-CA and FA were found in all tissues (except for $p$-CA in the brain). The reason why $p$-CA was higher in tissues (except for the brain) is that the transepithelial transport of $p$-CA depends on concentration and saturation (Konishi, Kobayashi, Shimizu, 2003), and higher FA levels in the intestine could partly be attributed to gradual efflux from the stomach. CA was only observed in the stomach and intestine at the different five points, and in the muscle at the first point. Both QUER and HP are flavonoids, and their behaviors were basically consistent in vivo after gavage (Table VI). QUER was abundant in the stomach and intestine but only a little was found in the liver, and the highest concentrations of HP were in the stomach with low levels in the liver, kidney and intestine; HP was not found in other tissues. Bacteria and/or enzymerelated hydrolysis of HP in the gastrointestinal tract is an important factor responsible for the poor absorption of $\mathrm{HP}$, and its absorption might depend on the type of sugar moiety bonded to the aglycone (Chang et al., 2005).

\section{Excretion assay}

The cumulative ratios of the five analytes are 
TABLE I - Calibration curves, correlation coefficients and linear ranges of the five compounds in the tissue samples

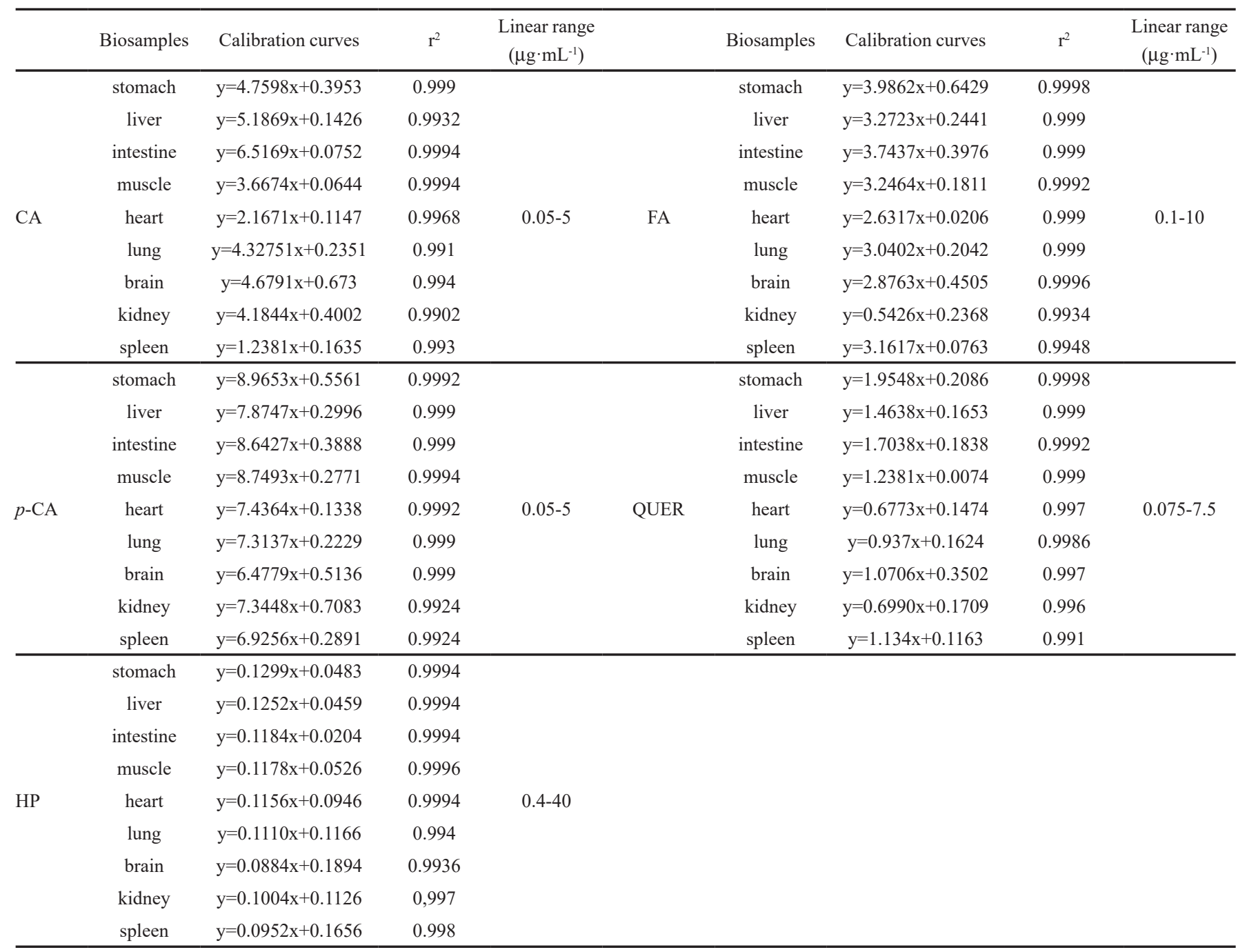

$y$, peak area ratio; $x$, concentration of the reference standard $\left(\mu \mathrm{g} \cdot \mathrm{mL}^{-1}\right) ; r$, correlation coefficient.

TABLE II - Calibration curves, correlation coefficients and linear ranges of the five compounds in the urine/feces samples

\begin{tabular}{lcccc}
\hline & Biosamples & Calibration curves & $\mathrm{r}^{2}$ & Linear ranges $\left(\mu \mathrm{g} \cdot \mathrm{mL}^{-1}\right)$ \\
\hline CA & Urine & $\mathrm{y}=0.4509 \mathrm{x}-0.0432$ & 0.996 & $0.15-60$ \\
& Feces & $\mathrm{y}=0.9042 \mathrm{x}-0.128$ & 0.991 & \\
\hline$p$-CA & Urine & $\mathrm{y}=0.6069 \mathrm{x}+0.043$ & 0.992 & $0.125-100$ \\
& Feces & $\mathrm{y}=2.2008 \mathrm{x}-0.2654$ & 0.992 & $0.0875-87.5$ \\
\hline FA & Urine & $\mathrm{y}=0.1407 \mathrm{x}+0.1069$ & 0.996 & $0.1875-75$ \\
& Feces & $\mathrm{y}=0.2456 \mathrm{x}+0.047$ & 0.996 & \\
\hline QUER & Urine & $\mathrm{y}=0.0345 \mathrm{x}+0.0258$ & 0.998 & $1.25-75$ \\
& Feces & $\mathrm{y}=0.0175 \mathrm{x}+0.0526$ & 0.994 & \\
\hline HP & Urine & $\mathrm{y}=0.4509 \mathrm{x}-0.0432$ & 0.992 & 0.996 \\
& Feces & $\mathrm{y}=0.9042 \mathrm{x}-0.128$ & & \\
\hline
\end{tabular}

$y$, peak area ratio; $x$, concentration of the reference standard $\left(\mu \mathrm{g} \cdot \mathrm{mL}^{-1}\right) ; r$, correlation coefficient. 
TABLE III - Extraction recovery, precision, accuracy and stability of the five compounds in stomach. $(n=5)$

\begin{tabular}{cccccccccccc}
\hline & \multirow{2}{*}{$\begin{array}{c}\text { Added conc. } \\
\left(\mu \mathrm{g} \cdot \mathrm{mL}^{-1}\right)\end{array}$} & $\begin{array}{c}\text { Extraction } \\
\text { recovery }\end{array}$ & $\begin{array}{c}\text { Found conc. } \\
\left(\mu \mathrm{g} \cdot \mathrm{mL}^{-1}\right)\end{array}$ & $\begin{array}{c}\text { RSD } \\
(\%)\end{array}$ & $\begin{array}{c}\text { RE } \\
(\%)\end{array}$ & $\begin{array}{c}\text { Found conc. } \\
\left.(\mu \mathrm{g} \cdot \mathrm{mL})^{-1}\right)\end{array}$ & $\begin{array}{c}\text { RSD } \\
(\%)\end{array}$ & $\begin{array}{c}\text { RE } \\
(\%)\end{array}$ & $\begin{array}{c}\text { Short-term } \\
\text { stability }\end{array}$ & $\begin{array}{c}\text { Long-term } \\
\text { stability }\end{array}$ & $\begin{array}{c}\text { Freeze-thaw } \\
\text { stability }\end{array}$ \\
\hline \multirow{4}{*}{ CA } & 0.125 & $84.41 \pm 0.92$ & $0.12 \pm 0.01$ & 6.40 & -3.3 & $0.12 \pm 0.01$ & 5.07 & -3.2 & $90.90 \pm 0.95$ & $88.41 \pm 0.92$ & $94.25 \pm 2.07$ \\
& 0.7 & $86.96 \pm 2.22$ & $0.66 \pm 0.01$ & 1.67 & -6.2 & $0.67 \pm 0.03$ & 4.70 & -6.4 & $86.48 \pm 4.88$ & $86.96 \pm 2.22$ & $86.12 \pm 2.46$ \\
& 4 & $91.03 \pm 1.74$ & $3.76 \pm 0.10$ & 2.53 & -5.9 & $3.69 \pm 0.12$ & 3.12 & -7.7 & $92.51 \pm 3.50$ & $94.03 \pm 4.88$ & $91.67 \pm 5.10$ \\
\hline & 0.125 & $85.36 \pm 0.55$ & $0.12 \pm 0.03$ & 1.66 & -3.1 & $0.12 \pm 0.01$ & 5.92 & -3.9 & $91.97 \pm 1.57$ & $85.36 \pm 0.55$ & $85.98 \pm 1.17$ \\
$p$-CA & 0.7 & $87.48 \pm 3.09$ & $0.67 \pm 0.03$ & 4.04 & -4.7 & $0.66 \pm 0.01$ & 0.83 & -6.2 & $86.56 \pm 4.08$ & $87.48 \pm 3.09$ & $88.62 \pm 0.49$ \\
& 4 & $90.35 \pm 1.13$ & $3.73 \pm 0.07$ & 1.94 & -6.8 & $3.72 \pm 0.03$ & 0.78 & -7.0 & $85.06 \pm 5.11$ & $90.35 \pm 4.13$ & $93.48 \pm 4.94$ \\
\hline & 0.125 & $82.14 \pm 1.03$ & $0.13 \pm 0.01$ & 4.10 & 3.2 & $0.13 \pm 0.02$ & 2.16 & 0.3 & $92.54 \pm 0.90$ & $97.14 \pm 3.03$ & $102.5 \pm 4.06$ \\
FA & 0.7 & $86.52 \pm 3.07$ & $0.72 \pm 0.05$ & 7.11 & 2.8 & $0.75 \pm 0.01$ & 1.86 & 6.6 & $108.0 \pm 2.85$ & $106.5 \pm 3.07$ & $93.24 \pm 0.31$ \\
& 4 & $83.64 \pm 2.78$ & $4.20 \pm 0.14$ & 3.38 & 4.9 & $4.23 \pm 0.09$ & 2.18 & 5.8 & $103.3 \pm 0.07$ & $100.6 \pm 2.78$ & $105.3 \pm 5.75$ \\
\hline & 0.188 & $84.39 \pm 2.08$ & $0.18 \pm 0.01$ & 6.70 & -2.5 & $0.179 \pm 0.01$ & 7.10 & -5.0 & $97.29 \pm 1.81$ & $99.39 \pm 2.08$ & $87.29 \pm 2.78$ \\
QUER & 1.05 & $93.04 \pm 3.45$ & $1.01 \pm 0.02$ & 1.79 & -3.8 & $1.01 \pm 0.10$ & 9.91 & -4.0 & $88.40 \pm 5.83$ & $93.04 \pm 3.45$ & $88.93 \pm 4.41$ \\
& 6 & $87.01 \pm 4.80$ & $5.62 \pm 0.15$ & 2.74 & -6.4 & $5.98 \pm 0.16$ & 2.65 & -0.4 & $109.6 \pm 1.35$ & $87.01 \pm 4.80$ & $92.36 \pm 5.47$ \\
\hline & 4 & $82.55 \pm 1.55$ & $3.78 \pm 0.10$ & 2.65 & -5.51 & $3.81 \pm 0.17$ & 4.53 & -4.79 & $89.64 \pm 3.77$ & $91.55 \pm 1.55$ & $88.98 \pm 3.68$ \\
HP & 22.4 & $93.62 \pm 2.71$ & $23.17 \pm 1.65$ & 7.11 & 3.45 & $23.72 \pm 1.16$ & 4.88 & 5.90 & $103.9 \pm 3.53$ & $99.62 \pm 2.71$ & $94.46 \pm 4.85$ \\
& 127.68 & $86.40 \pm 3.60$ & $118.9 \pm 1.04$ & 0.87 & -6.92 & $119.2 \pm 2.11$ & 1.77 & -6.67 & $87.10 \pm 3.73$ & $86.40 \pm 4.60$ & $89.85 \pm 4.15$ \\
\hline
\end{tabular}

TABLE IV - Extraction recovery, precision, accuracy and stability of the five compounds in urine. $(n=5)$

\begin{tabular}{cccccccccccc}
\hline & \multirow{2}{*}{$\begin{array}{c}\text { Added conc. } \\
\left(\mu \mathrm{g} \cdot \mathrm{mL}^{-1}\right)\end{array}$} & $\begin{array}{c}\text { Extraction } \\
\text { recovery }\end{array}$ & $\begin{array}{c}\text { Found conc. } \\
\left(\mu \mathrm{g} \cdot \mathrm{mL}^{-1}\right)\end{array}$ & $\begin{array}{c}\text { RSD } \\
(\%)\end{array}$ & $\begin{array}{c}\text { RE } \\
(\%)\end{array}$ & $\begin{array}{c}\text { Found conc. } \\
\left(\mu \mathrm{g} \cdot \mathrm{mL}^{-1}\right)\end{array}$ & $\begin{array}{c}\text { RSD } \\
(\%)\end{array}$ & $\begin{array}{c}\text { RE } \\
(\%)\end{array}$ & $\begin{array}{c}\text { Short-term } \\
\text { stability }\end{array}$ & $\begin{array}{c}\text { Long-term } \\
\text { stability }\end{array}$ & $\begin{array}{c}\text { Freeze-thaw } \\
\text { stability }\end{array}$ \\
\hline \multirow{4}{*}{ CA } & 0.375 & $86.41 \pm 0.42$ & $0.37 \pm 0.01$ & 0.60 & -1.1 & $0.38 \pm 0.01$ & 0.72 & 0.3 & $100.9 \pm 0.01$ & $100.8 \pm 0.02$ & $98.78 \pm 0.03$ \\
& 4.25 & $85.66 \pm 1.22$ & $4.30 \pm 0.02$ & 0.42 & 1.1 & $4.43 \pm 0.21$ & 4.75 & 4.2 & $104.3 \pm 0.06$ & $102.8 \pm 0.17$ & $100.8 \pm 0.04$ \\
& 48 & $91.43 \pm 1.54$ & $49.12 \pm 1.05$ & 2.14 & 2.3 & $49.30 \pm 0.36$ & 0.74 & 2.7 & $103.9 \pm 0.93$ & $101.1 \pm 1.10$ & $110.1 \pm 1.20$ \\
\hline \multirow{4}{*}{ P-CA } & 0.625 & $88.36 \pm 0.95$ & $0.64 \pm 0.02$ & 3.15 & 2.4 & $0.65 \pm 0.03$ & 5.01 & 4.7 & $105.7 \pm 0.04$ & $105.5 \pm 0.03$ & $102.3 \pm 0.02$ \\
& 7.07 & $89.48 \pm 2.09$ & $7.39 \pm 0.07$ & 0.91 & 4.6 & $7.62 \pm 0.28$ & 3.74 & 7.8 & $107.9 \pm 0.02$ & $106.4 \pm 0.22$ & $104.3 \pm 0.04$ \\
& 80 & $92.35 \pm 1.33$ & $86.43 \pm 1.82$ & 2.11 & 8.0 & $82.73 \pm 0.59$ & 0.71 & 3.4 & $109.7 \pm 1.60$ & $106.7 \pm 1.98$ & $106.3 \pm 2.16$ \\
\hline \multirow{3}{*}{ FA } & 0.22 & $87.14 \pm 1.53$ & $0.22 \pm 0.01$ & 2.72 & 0.6 & $0.23 \pm 0.01$ & 2.55 & 2.9 & $103.9 \pm 0.02$ & $103.8 \pm 0.01$ & $100.4 \pm 0.01$ \\
& 3.91 & $88.52 \pm 2.07$ & $3.76 \pm 0.02$ & 0.50 & -3.8 & $3.88 \pm 0.19$ & 4.77 & -0.8 & $99.31 \pm 0.05$ & $97.90 \pm 0.15$ & $95.99 \pm 0.03$ \\
& 70.00 & $81.64 \pm 2.48$ & $72.56 \pm 1.6$ & 2.20 & 3.7 & $65.82 \pm 0.61$ & 0.92 & -6.0 & $105.3 \pm 1.27$ & $102.4 \pm 1.89$ & $101.3 \pm 1.62$ \\
\hline & 0.47 & $82.39 \pm 1.08$ & $0.48 \pm 0.04$ & 8.26 & 1.6 & $0.50 \pm 0.02$ & 3.65 & 6.7 & $108.9 \pm 0.04$ & $108.7 \pm 0.03$ & $101.3 \pm 0.04$ \\
QUER & 5.30 & $93.04 \pm 3.45$ & $5.28 \pm 0.08$ & 1.46 & -0.5 & $4.94 \pm 0.30$ & 6.14 & -6.8 & $103.2 \pm 0.12$ & $101.6 \pm 0.28$ & $99.30 \pm 0.10$ \\
& 60.00 & $89.01 \pm 2.80$ & $55.59 \pm 1.88$ & 3.39 & -7.4 & $65.40 \pm 0.50$ & 0.76 & 9.0 & $94.16 \pm 2.41$ & $91.59 \pm 3.24$ & $99.96 \pm 3.75$ \\
\hline & 3.13 & $85.55 \pm 1.45$ & $3.28 \pm 0.12$ & 3.53 & 4.8 & $3.35 \pm 0.11$ & 3.34 & 7.3 & $108.5 \pm 0.19$ & $108.3 \pm 0.08$ & $104.7 \pm 0.1$ \\
HP & 13.69 & $93.62 \pm 2.71$ & $14.16 \pm 0.13$ & 0.92 & 3.5 & $14.63 \pm 0.69$ & 4.71 & 6.8 & $106.9 \pm 0.16$ & $105.4 \pm 0.56$ & $103.2 \pm 0.14$ \\
& 60.00 & $84.40 \pm 3.60$ & $61.14 \pm 1.30$ & 2.12 & 1.9 & $59.94 \pm 0.37$ & 0.61 & -0.1 & $103.5 \pm 1.22$ & $100.6 \pm 1.32$ & $109.9 \pm 1.48$ \\
\hline
\end{tabular}

listed in Figure 3. Six hours after delivery, CA and FA all reached maximum excretion in the urine and feces, and were eliminated slowly after that. The cumulative ratios after $24 \mathrm{~h}$ were above $90 \%$ in the total excreta, indicating that they were completely eliminated within $24 \mathrm{~h}$ after oral administration. In the combined results of the tissue distributions analysis, $p$-CA was abundant in all tissues except for brain, but the low cumulative ratio of $p$-CA, i.e. $3.70 \pm 0.25 \%$ after $24 \mathrm{~h}(3.36 \pm 0.24 \%$ in the urinary excretion and $0.04 \pm 0.01 \%$ in the fecal excretion) indicated that $p$-CA was directly absorbed into the bloodstream. QUER and HP also presented low 
TABLE V - Extraction recovery, precision, accuracy and stability of the five compounds in feces. $(n=5)$

\begin{tabular}{|c|c|c|c|c|c|c|c|c|c|c|c|}
\hline & \multirow{2}{*}{$\begin{array}{l}\text { Added conc. } \\
\left(\mu \mathrm{g} \cdot \mathrm{mL}^{-1}\right)\end{array}$} & \multirow{2}{*}{$\begin{array}{l}\text { Extraction } \\
\text { recovery }\end{array}$} & \multicolumn{3}{|c|}{ Intra-day } & \multicolumn{3}{|c|}{ Inter-day } & \multicolumn{3}{|c|}{ Accuracy $(\%$, mean \pm SD $)$} \\
\hline & & & $\begin{array}{l}\text { Found conc. } \\
\left(\mu \mathrm{g} \cdot \mathrm{mL}^{-1}\right)\end{array}$ & $\begin{array}{l}\text { RSD } \\
(\%)\end{array}$ & $\begin{array}{l}\mathrm{RE} \\
(\%)\end{array}$ & $\begin{array}{l}\text { Found conc. } \\
\left(\mu \mathrm{g} \cdot \mathrm{mL}^{-1}\right)\end{array}$ & $\begin{array}{l}\text { RSD } \\
(\%)\end{array}$ & $\begin{array}{l}\mathrm{RE} \\
(\%)\end{array}$ & $\begin{array}{l}\text { Short-term } \\
\text { stability }\end{array}$ & $\begin{array}{l}\text { Long-term } \\
\text { stability }\end{array}$ & $\begin{array}{c}\text { Freeze-thaw } \\
\text { stability }\end{array}$ \\
\hline \multirow[t]{2}{*}{$\mathrm{CA}$} & 4.25 & $89.96 \pm 2.52$ & $3.85 \pm 0.05$ & 1.35 & -9.5 & $3.89 \pm 0.13$ & 3.35 & -8.4 & $92.25 \pm 0.17$ & $90.68 \pm 0.04$ & $93.46 \pm 0.20$ \\
\hline & 48 & $91.43 \pm 1.44$ & $48.70 \pm 0.90$ & 1.84 & 1.5 & $44.69 \pm 0.74$ & 1.65 & -6.9 & $93.11 \pm 0.74$ & $94.29 \pm 1.15$ & $85.54 \pm 0.46$ \\
\hline \multirow{2}{*}{$\mathrm{P}-\mathrm{CA}$} & 80 & $91.35 \pm 1.33$ & $83.33 \pm 2.46$ & 2.95 & 4.2 & $76.45 \pm 2.22$ & 2.90 & -4.4 & $95.57 \pm 2.22$ & $96.73 \pm 1.1$ & $87.75 \pm 1.03$ \\
\hline & 0.22 & $85.14 \pm 1.23$ & $0.22 \pm 0.01$ & 4.46 & 1.8 & $0.23 \pm 0.01$ & 2.26 & 5.2 & $105.2 \pm 0.01$ & $101.9 \pm 0.01$ & $99.27 \pm 0.01$ \\
\hline \multirow[t]{2}{*}{ FA } & 3.91 & $89.52 \pm 3.17$ & $4.15 \pm 0.04$ & 1.07 & 6.1 & $4.23 \pm 0.15$ & 3.66 & 8.2 & $104.3 \pm 0.18$ & $106.3 \pm 0.04$ & $104.4 \pm 0.23$ \\
\hline & 70.00 & $88.64 \pm 2.38$ & $69.51 \pm 2.32$ & 3.34 & -0.7 & $63.78 \pm 1.78$ & 2.78 & -8.9 & $97.48 \pm 4.91$ & $92.23 \pm 1.58$ & $95.97 \pm 1.52$ \\
\hline QUER & 3.13 & $85.55 \pm 1.53$ & $3.23 \pm 0.21$ & 6.46 & 3.3 & $3.34 \pm 0.23$ & 7.00 & 6.9 & $106.9 \pm 0.23$ & $103.4 \pm 0.23$ & $105.9 \pm 0.28$ \\
\hline \multirow[t]{2}{*}{ HP } & 13.69 & $93.65 \pm 2.41$ & $12.56 \pm 0.29$ & 2.30 & -8.2 & $12.82 \pm 0.26$ & 2.05 & -6.4 & $93.60 \pm 0.26$ & $97.76 \pm 0.26$ & $94.89 \pm 0.29$ \\
\hline & 60.00 & $86.70 \pm 3.31$ & $64.21 \pm 1.65$ & 2.57 & 7.0 & $64.45 \pm 2.30$ & 3.56 & 7.4 & $98.09 \pm 1.57$ & $99.33 \pm 1.37$ & $97.14 \pm 0.22$ \\
\hline
\end{tabular}

TABLE VI - Concentrations of CA, $p$-CA, FA, QUER and HP in different rat tissues after oral administration of POE $(n=5)$

\begin{tabular}{|c|c|c|c|c|c|c|c|c|c|c|}
\hline & \multirow{2}{*}{$\begin{array}{l}\text { Time } \\
\text { (min) }\end{array}$} & \multicolumn{9}{|c|}{ Concentration $\left(\mu \mathrm{g} \cdot \mathrm{g}^{-1}\right)$} \\
\hline & & Liver & Intestine & Stomach & Muscle & Heart & Lung & Brain & Kidney & Spleen \\
\hline \multirow[t]{3}{*}{$\mathrm{CA}$} & 10 & - & $1.18 \pm 0.20$ & $2.18 \pm 0.23$ & $0.290 \pm 0.03$ & - & - & - & - & - \\
\hline & 60 & - & $0.628 \pm 0.04$ & $1.95 \pm 0.20$ & - & - & - & - & - & - \\
\hline & 90 & - & $0.611 \pm 0.02$ & $1.64 \pm 0.10$ & - & - & - & - & - & - \\
\hline \multirow{4}{*}{$p$-CA } & 30 & $0.00740 \pm 0.0003$ & $0.0236 \pm 0.01$ & $1.13 \pm 0.03$ & $0.0114 \pm 0.003$ & $0.0144 \pm 0.003$ & $0.0420 \pm 0.003$ & - & $0.0580 \pm 0.03$ & $0.0228 \pm 0.001$ \\
\hline & 60 & $0.00582 \pm 0.0007$ & $0.0351 \pm 0.003$ & $1.53 \pm 0.03$ & - & $0.0459 \pm 0.007$ & $0.0534 \pm 0.02$ & - & $0.0601 \pm 0.007$ & $0.0136 \pm 0.03$ \\
\hline & 90 & $0.0148 \pm 0.003$ & $0.0944 \pm 0.03$ & $1.99 \pm 0.10$ & - & $0.0364 \pm 0.003$ & $0.0490 \pm 0.03$ & - & $0.0396 \pm 0.002$ & $0.0142 \pm 0.002$ \\
\hline & 150 & - & $0.0320 \pm 0.003$ & $1.13 \pm 0.04$ & $0.0144 \pm 0.003$ & $0.0312 \pm 0.003$ & $0.0672 \pm 0.001$ & - & $0.0484 \pm 0.02$ & $0.0316 \pm 0.0007$ \\
\hline FA & 150 & - & $1.79 \pm 0.07$ & $10.0 \pm 0.50$ & $0.145 \pm 0.09$ & - & - & $0.373 \pm 0.09$ & $0.822 \pm 0.03$ & $0.147 \pm 0.02$ \\
\hline \multirow[t]{5}{*}{ QUER } & 10 & $0.0290 \pm 0.01$ & $0.146 \pm 0.004$ & $0.0279 \pm 0.10$ & - & - & - & - & - & - \\
\hline & 30 & $0.0127 \pm 0.001$ & - & $0.213 \pm 0.04$ & - & - & - & - & - & - \\
\hline & 60 & $0.0462 \pm 0.004$ & - & $0.772 \pm 0.06$ & - & - & - & - & - & - \\
\hline & 90 & - & $0.580 \pm 0.07$ & $0.190 \pm 0.04$ & - & - & - & - & - & - \\
\hline & 150 & - & $3.05 \pm 0.04$ & $0.253 \pm 0.03$ & - & - & - & - & - & - \\
\hline \multirow[t]{3}{*}{ HP } & 10 & $10.6 \pm 2.0$ & $9.59 \pm 1.3$ & $530.2 \pm 4.00$ & - & - & - & - & - & - \\
\hline & 30 & $5.63 \pm 1.0$ & - & $182.7 \pm 3.00$ & $11.9 \pm 0.23$ & - & - & - & $6.00 \pm 0.20$ & - \\
\hline & 60 & $13.9 \pm 0.67$ & - & $140.8 \pm 4.13$ & - & - & - & - & $4.11 \pm 0.08$ & - \\
\hline
\end{tabular}


cumulative ratios, indicating that extensive metabolism and excretion via other routes might occur, or a higher tissue distribution might occur.

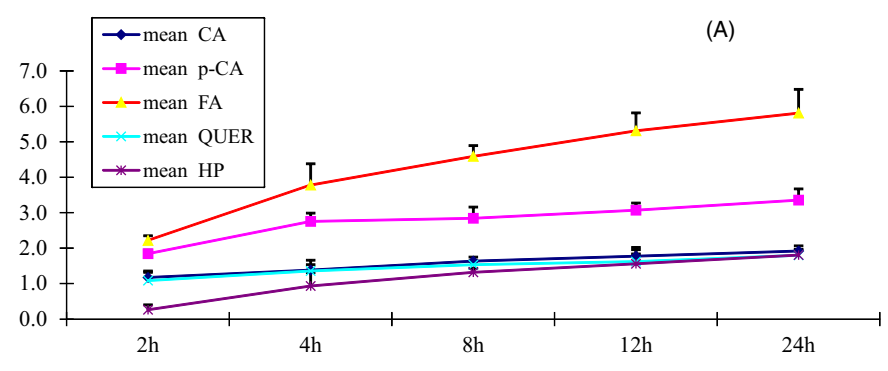

(B)

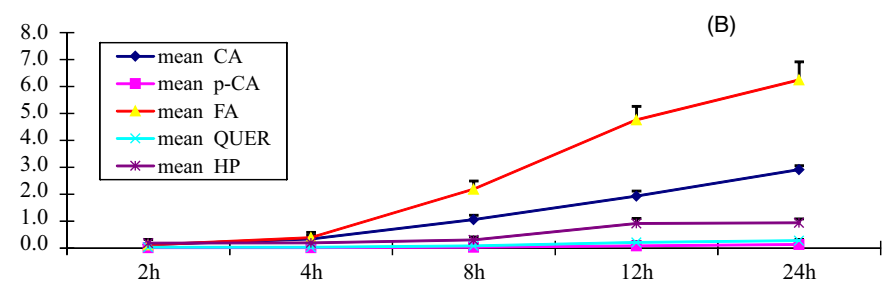

FIGURE 3 - (A) Urinary cumulative ratios of the five analytes in rats (mean $\pm \mathrm{SD}, n=5$ ) following oral administration of POE. (B) Fecal cumulative ratios of the five analytes in rats (mean \pm $\mathrm{SD}, n=5$ ) following oral administration of POE.

\section{CONCLUSIONS}

A rapid, sensitive and specific UHPLC method with the internal standard was developed and validated for the determination of five components in POE. At the same time, the behavior of these five components of POE was also characterized in rat tissues after oral administration. Taken together, the study on tissue distributions and excretion of these five components of POE is of significance for its clinic applications in the future.

\section{ACKNOWLEDGMENTS}

This study was supported by the Project of National Natural Science Foundation of China (Grant No.81573546).

\section{REFERENCES}

CHANG, Q.; ZUO, Z.; MOSES, S.S.C.; WALTER, K.K.H. Difference in absorption of the two structurally similar flavonoid glycosides, hyperoside and isoquercitrin, in rats. Eur. J. Pharm. Biopharm. , v. 59, n.3, p.549-555, 2005.
CHENG, Z.Z.; XIE, M.; ZHANG, W.J.; CHENG, L.; DU, Y.; WANG, Y.J.; YING, X.X.; KANG, T.G. HPLC method for the simultaneous determination of four compounds in rat plasma after intravenous administration of Portulaca oleracea L. extract. Braz. J. Pharm. Sci., v.48, n.1, p.163170, 2012.

FOOD AND DRUG ADMINISTRATION. FDA. Guidance for industry : bioanalytical method validation. Rockville, US : Department of Health and Human Services, Food and Drug Administration, Center for Drug Evaluation And Research (CDER), 2001. Available at: <www.fda.gov/downloads/ Drugs/GuidanceComplianceRegulatoryInformation/ Guidances/UCM070107.pdf $>$. Accessed on May 05, 2001.

GONG, F.Y.; LI, F.L.; ZHANG L.L.; LI, J.; ZHANG, Z.; WANG, G. Hypoglycemic effects of crude polysaccharide from purslane. Int. J. Mol. Sci.,v.10, n.3, p.880-888, 2009.

KONISHI, Y.; KOBAYASHI, S.; SHIMIZU, M. Transepithelial transport of p-coumaric acid and gallic acid in Caco-2 cell monolayers. Biosci., Biotech. Biochem., v.67, n.11, p.23172324, 2003.

LIM, Y.Y.; KIM, H.M.; PARK, W.S.; KIM, J.H.; SHIN, H.J.; KIM, M.N. Anti-inflammatory and anti-pruritic effects of Portulaca oleracea L. Extract using in vitro and in vivo inflammation model: LPS-treated raw264. 7 Cells, keratinocytes, NC/Nga mice and hairless SKH-1 mice. Korean J. Asthma, Allergy and Clin. Immunol., v.31, p.199206, 2011.

MOVAHEDIAN, A.; GHANNADI, A.; VASHIMIA, M. Hypocholesterolemic effects of purslane extract on serum lipids in rabbits fed with high cholesterol levels. Int. J. Pharmacol., v.3, n.3, p.285-289, 2007.

The Pharmacopoeia of the People's Republic of China. Beijing: China Medical Science and Technology Press, 2010. v.1, p.46. $3382 \mathrm{p}$.

XU, X.Q.; YU, L.S.; CHEN, G.N. Determination of flavonoids in Portulaca oleracea L. by capillary electrophoresis with electrochemical detection. J. Pharm. Biomed. Anal., v.41, n.2, p.493-499, 2006.

Received for publicationon on $14^{\text {th }}$ October 2014 Accepted for publicationon on $26^{\text {th }}$ June 2015 
